\title{
Seroprevalence of Fasciola hepatica infection in cattle and sheep in the province of Kars, Turkey, as determined by ELISA
}

\author{
A. $\mathrm{AKCA}^{1 *}$, H. I. GOKCE ${ }^{2+}$, N. $\mathrm{MOR}^{1}$ \\ ${ }^{1}$ Department of Parasitology, Kafkas University, Faculty of Veterinary Medicine, Kars/Turkey, \\ *E-mail: atilaakca@hotmail.com; 리 Department of Internal Medicine, Kafkas University, Faculty of Veterinary Medi- \\ cine, Kars/Turkey; ${ }^{+}$Present address Mehmet Akif Ersoy University, Burdur/Turkey
}

\begin{abstract}
Summary
This study aimed to determine the seroprevalence of Fasciola hepatica infection in cattle and sheep in the province of Kars, Turkey. Serum samples from 500 cattle and 540 sheep, collected from 15 randomly selected localities (villages) in the region, were tested for the presence of anti- $F$. hepatica antibodies using an in-house ELISA test with $98 \%$ sensitivity and $96 \%$ specificity. The seroprevalence of $F$. hepatica in the district was determined to be $66.6 \%(333 / 500)$ in cattle and $93 \%(502 / 540)$ in sheep. There was also a statistically significant difference in the rates of seropositivity between villages (each of which could be considered to be a large herd or flock), ranging from $0 \%$ to $100 \%$ in cattle and from $68 \%$ to $100 \%$ in sheep, $\mathrm{P}<0.01)$. These findings show that $F$. hepatica infection is very common in the region; that, in contrast to results from abattoir which indicate a level of only $10 \%$ prevalence, the exposure of farm animals to the infection in the region is in fact very high; and that the risk of acquiring the infection varies between the localities and the host species tested within the region.
\end{abstract}

Key words: Fasciola; ELISA; cattle; sheep; Kars; Turkey

\section{Introduction}

Trematode parasites of the genus Fasciola infect a wide range of mammalian hosts, including humans, but cause economically important and serious disease in domesticated ruminants. Whereas $F$. hepatica is generally prevalent in areas where the climate is temperate and rainy, $F$. gigantica is more commonly found in tropical regions (Torgerson \& Claxton, 1999). In Turkey, both parasites are encountered, with $F$. hepatica highly prevalent (Akyol, 2003). In studies performed predominantly in abattoirs, the prevalence of fasciolosis in Turkey has been found to range from $4 \%$ to $68 \%$, depending upon the region and the host species investigated (Akyol, 2003). In the Eastern
Anatolia Region, in which this study was conducted, the prevalence of the infection was reported to be $41 \%$ in cattle and $62 \%$ in sheep in the earlier literature (Kurtpinar, 1957; Leloglu, 1972), and around $10 \%$ in a more recent investigation performed in the vicinity of Kars (Gicik et al., 2002). However, it is suspected that in reality, the prevalence of the infection may be much higher in the field. Although the specificity of the faecal examination methods commonly employed to diagnose the infection is relatively high, their sensitivity is rather low (Happich \& Boray, 1969), and they have no diagnostic value in the acute phase of the infection. Nonetheless, this problem has been largely resolved in recent years through the development of a variety of very sensitive and specific serological tests, including ELISA (Hillyer, 1999; Molley et al., 2005; Salimi-Bejestani et al., 2005). Moreover, these methods have been found to be both easy to implement and reliable in fieldwork (Rapsch et al., 2006; Duscher et al., 2011).

The aim of this pilot study was to determine, by ELISA, the seroprevalence of fasciolosis in cattle and sheep in Kars and its vicinity, an area which has a significant capacity for animal husbandry.

\section{Materials and methods}

Study area

The province of Kars is situated in north-eastern Turkey, at a latitude of $40.6^{\circ} \mathrm{N}$ and a longitude of $43.1^{\circ} \mathrm{E}$. The province is divided into eight provincial towns including the central city of Kars, which administer a total of 386 villages. The region covers an area of $9587 \mathrm{~km}^{2}$, and the dominant features of the landscape are wide highland plateaux located between mountain ranges, at an average altitude of 1768 metres. The climate of the area ranges from very cold in mid-winter (with a mean monthly temperature [MMT] of $-10.1{ }^{\circ} \mathrm{C}$ in January) to mild throughout the summer months (MMTs range from 13.8 to $17.7^{\circ} \mathrm{C}$ ). MMTs above 
$10{ }^{\circ} \mathrm{C}$ are recorded from May to September. Mean monthly lowest temperatures of above $10{ }^{\circ} \mathrm{C}$ occur only in July and August; mean monthly highest temperatures rise above $10{ }^{\circ} \mathrm{C}$ in the months from April to October, inclusive. The area receives rainfall all year around, with a mean annual rainfall of $489 \mathrm{~kg} / \mathrm{m}^{2}$. While the highest rainfall occurs in May and June with mean monthly rainfall figures of 77.7 and $73.1 \mathrm{~kg} / \mathrm{m}^{2}$, respectively, the lowest rainfall occurs in the winter months as snow. However, as the snow which has accumulated during the winter, particularly in the mountains, gradually melts during the warm spring and summer months, areas of enduring wetland are formed. Typical relative humidity in the area is approximately $71 \%$.

The province and its surroundings are the one of the most important areas for the rearing of farm animals in Turkey, with just above 300 thousand cattle and approximately 350 thousand sheep recorded in the 2004 inventory.

\section{Collection of samples}

Fifteen localities (villages) were randomly selected for each animal species and blood samples were collected from cattle (500) and sheep (540) during the summer and autumn of the year 2003. A ten ml blood sample was taken from the jugular vein of each animal into evacuated tubes, and transported to the Parasitology Laboratory of the Faculty of Veterinary Medicine, Kafkas University, Kars. Serum was removed from the clotted blood samples by centrifugation at $4000 \mathrm{rpm}$ for 10 minutes, and stored at $20{ }^{\circ} \mathrm{C}$, until tested for the presence of anti- $F$. hepatica antibodies by ELISA.

\section{Serological testing}

An in-house ELISA test was employed to detect the antibodies. The test was performed as previously described by Salimi-Bejestani et al. (2005) and Akca (1999), with minor modifications. The assay had $98 \%$ sensitivity and $96 \%$ specificity. Briefly, flat-bottomed, 96-well ELISA plates (Nunc Maxisorp) were coated with $100 \mu \mathrm{l}$ per well of $1 \mu \mathrm{g} / \mathrm{ml}$ of excreted and secreted (E/S) antigens of $F$. hepatica, prepared as described elsewhere (Akca, 1999; Salimi-Bejestani et al., 2005), in $0.1 \mathrm{M}$ carbonate bicarbonate buffer ( $\mathrm{pH}$ 9.6). Following overnight incubation, the plates were washed 6 times (four short washes and two five min washes) with PBS ( $\mathrm{pH} 7.2)$ containing $0.05 \%$ Tween-20 (PBS/Tween), and blocked with $200 \mu \mathrm{l}$ per well of a solution containing $3 \%$ skimmed-milk powder (Marvel, Premier Beverages, Stafford, UK) in PBS $/ 0.05 \%$ Tween-20 for 1 hour at $37^{\circ} \mathrm{C}$. After a further washing cycle, $100 \mu \mathrm{l}$ of $1: 400$ diluted serum samples was added to the wells in duplicate and incubated for $1 \mathrm{~h}$ at $37{ }^{\circ} \mathrm{C}$. Negative and positive control sera were included in each plate and tested in duplicate. The plates were then washed then as before and $100 \mu \mathrm{l}$ per well of horse radish peroxidase conjugated antibovine or anti-ovine IgG antibodies (Sigma) diluted 1:10,000 in PBS/Tween was added to the plates which were then incubated for a further 1 hour at $37^{\circ} \mathrm{C}$. After a final washing step as before, $100 \mu \mathrm{l}$ of the freshly prepared substrate solution-TMB (hydrogen peroxide solution in acetate buffer $\mathrm{pH} 5.0$ and tetramethylbenzidine in a methanol based solution) was added to each well and the plates were left in darkness at room temperature for 15 minutes before the enzyme-substrate reaction was stopped with $50 \mu \mathrm{l}$ of $4 \mathrm{~N}$ sulphuric acid. The colour changes were then recorded at a wavelength of $450 \mathrm{~nm}$ on an automated ELISA reader (Tekan-Spectra, Austria). The results were expressed as the percent positivity (PP) of the test sera over the positive control sera, by the following formula:

Percent positivety $(\mathrm{PP})=$ Mean OD of test sample/Mean OD of positive control sera $X 100$

A test result of more than $15 \mathrm{PP}$ was considered to be a positive result.

\section{Statistical analysis}

Seroprevalence was expressed as the percent positive, and the differences in seroprevalence between the villages were analysed by the Chi-square test, using SPSS version 11 .

\section{Results}

The results of the study are set out in Table 1 (cattle) and Table 2 (sheep). The seroprevalence of fasciolosis in the province of Kars was found to be $66.6 \%$ (326/500) and $93 \%(502 / 540)$ in cattle and sheep, respectively. When the localities studied are taken into account, the rate of seropositivity was found to range from $0 \%$ to $100 \%$ in cattle, and from $68 \%$ to $100 \%$ in sheep. Statistically significant differences $(p<0.001)$ were found between the localities in terms of their levels of seropositivity.

Table 1. Seroprevalence of Fasciola hepatica infection in cattle in the province of Kars and its surroundings as determined by ELISA

\begin{tabular}{cccc}
\hline $\begin{array}{c}\text { Localities } \\
\text { (Villages) }\end{array}$ & $\begin{array}{c}\text { Numbers } \\
\text { of samples tested }\end{array}$ & \multicolumn{2}{c}{ Positive } \\
& & n & \% \\
\hline Bulanık & 35 & - & 0.0 \\
Çerme & 50 & 35 & 70.0 \\
Dikme & 19 & 19 & 100.0 \\
Karakale & 27 & 15 & 55.6 \\
Kümbetli & 37 & 25 & 67.6 \\
Verimli & 21 & 19 & 90.5 \\
Yücelen & 29 & 17 & 58.6 \\
Akyaka/B.Pirveli & 72 & 55 & 76.4 \\
Akyaka-2 & 50 & 24 & 48.0 \\
Ardahan/Çalabaş & 12 & 12 & 100.0 \\
Arpaçay/Aslanizi & 19 & 19 & 100.0 \\
Ç1ldı̈/Gölbelen & 38 & 38 & 100.0 \\
Digor/Merkez & 27 & 21 & 77.8 \\
Kafkas Üniv. Çiftlik & 51 & 24 & 47.1 \\
Selim/Belliahmet & 13 & 10 & 76.9 \\
\hline Total & $\mathbf{5 0 0}$ & $\mathbf{3 3 3}$ & $\mathbf{6 6 . 6}$ \\
\hline
\end{tabular}

$\mathrm{x}^{2}=143.663 ; \mathrm{P}<0.001 \mathrm{n}-$ number of positive results 
Table 2. Seroprevalence of Fasciola hepatica infection in sheep in the province of Kars as determined by ELISA

\begin{tabular}{cccc}
\hline $\begin{array}{c}\text { Localities } \\
\text { (Villages) }\end{array}$ & $\begin{array}{c}\text { Numbers of } \\
\text { samples tested }\end{array}$ & \multicolumn{2}{c}{ Positive } \\
& & $\mathbf{n}$ & $\mathbf{\%}$ \\
\hline Kars/Merkez & 40 & 27 & 67.5 \\
Çerme & 11 & 11 & 100.0 \\
Hasçiftlik & 22 & 22 & 100.0 \\
Kümbetli & 50 & 50 & 100.0 \\
Oğuzlu & 52 & 50 & 96.2 \\
Yücelen & 21 & 21 & 100.0 \\
Akyaka/B.Pirveli & 48 & 47 & 97.9 \\
Arpaçay/Koç köy & 24 & 24 & 100.0 \\
Arpaçay & 77 & 75 & 97.4 \\
Digor/Alacaköy & 40 & 38 & 95.0 \\
Kağ1zman/Esenkır & 19 & 13 & 68.4 \\
Kağ1zman/Kuloğlu & 30 & 23 & 76.7 \\
Sarıkamış/Hamamlı̈̈y & 40 & 38 & 95.0 \\
Selim/Yalnız̧am & 49 & 49 & 100.0 \\
Susuz/Yolboyu köyü & 17 & 14 & 82.4 \\
\hline Total & $\mathbf{5 4 0}$ & $\mathbf{5 0 2}$ & $\mathbf{9 3 . 0}$ \\
\hline
\end{tabular}

$\mathrm{x}^{2}=91.07 ; \mathrm{P}<0.001 \mathrm{n}-$ number of positive results

\section{Discussion}

The findings indicate that fasciolosis is highly prevalent in the province of Kars. In recent studies, conducted in various parts of Turkey, findings from faecal examinations and abattoir research have revealed that the prevalence of the infection ranges between $4 \%$ and $68 \%$ (Akyol, 2003). Whereas the level of prevalence has fallen to single figures in the region of Thrace, the rate of infection remains rather high in the Black Sea Region (Gargili et al., 1999; Akyol, 2003). In a recent abattoir study undertaken in Kars, the level of fasciolosis in sheep was found to be around $10 \%$ (Gicik et al., 2002). Moreover, the proportion of false negative findings in this type of research should not be underestimated. The rate at which animals are slaughtered and the unsuitability of the conditions under which examinations are carried out increase the likelihood that the presence of parasites may be overlooked, particularly in cases of mild infection (Rapsch et al., 2006). Likewise, the fact that the parasites are small and embedded in the parenchyma in the prepatent phase of the infection significantly reduces the probability of detecting the infective agent under abattoir conditions. Moreover, when the fact that animals sent to the abattoir have usually been treated with anti-parasite drugs and fattened prior to slaughter is taken into consideration, it becomes evident that the use of abattoir data is less than sufficient to determine accurately the level of prevalence in a region. In a comparative study performed in Switzerland, Rapsch et al. (2006) found that while the level of sensitivity of abattoir results was $64 \%$, in contrast the diagnostic sensitivity of the ELISA test was $93 \%$. Likewise, in a more recent study monitoring fasciolosis in dairy herds in Carinthia Austria, Duscher et al. (2011) found that both individual milk ELISAs (42.7\% to
$44.2 \%$ ) and blood serum ELISAs (43\% to $45.2 \%$ ) are more sensitive than faecal examination for fluke eggs (coproscopy) (17.8\%) and than copro-antigen ELISA (13.4\%). On the other hand, it should be borne in mind that the indirect serological diagnostic method (ELISA) used in this study may indicate a level of prevalence slightly higher than it is in reality. Specifically, this test may continue to yield positive results for months in animals which have recovered from or been treated for the disease (Akca, 1999). The ELISA test used here has been evaluated using serum from animals infected experimentally and naturally with many parasites including $F$. hepatica, Dictyocaulus viviparous, Nematodirus helvetianus and Ostertagia ostertagi, and has been found to have $98 \%$ sensitivity and $96 \%$ specificity (Salimi-Bejestani et al., 2005). However, it has not yet been investigated in respect of the likelihood of cross-reactivity between Fasciola and related trematodes, in particular Dicrocoelium dendriticum and Paramphistomum $s p$. which occur commonly in the area in which the study was undertaken. Nonetheless, it has been reported that the ELISA tests developed for Fasciola do not produce a significant cross-reaction with the genus Paramphistomum (Molloy et al., 2005). Moreover, using the immunoblot technique, serum from animals infected with $D$. dendriticum has been shown to stain only for $F$. hepatica E/S antigens of high molecular weight (Sarimehmetoglu, 2002). Therefore, it is evident that caution should be exercised, in particular when evaluating weakly positive results obtained using the ELISA technique.

A variety of environmental and ecological factors constrain the development both of Fasciola species and of the snails which are their intermediate host. Factors such as the ambient temperature and humidity, the availability of water and the $\mathrm{pH}$ levels of soil are of vital importance to the parasite and its host (Tinar, 2003). In regions where rainfall is heavy and the temperature mild, the intermediate hosts may be expected to be distributed over a wide area, whereas in regions where rainfall is comparatively less heavy and where the summers are dry, the intermediate hosts may be expected to be concentrated in the beds of streams and rivers, in the vicinity of lakes, and in places where rainwater may collect and remain for long periods. In this study, it was established that the distribution of fasciolosis in the region was not homogenous. While anti$F$. hepatica antibodies were not detected in samples from only one of the localities studied, in the remaining areas the level of prevalence was found to range between $60 \%$ and $100 \%$. In the region, villages are generally located close to sources of water such as streams, rivers, lakes and ponds. Whereas the level of prevalence was $100 \%$ in those villages with large areas of wetland (pasture), in the other villages, it was found to be lower. The village in which Fasciola antibodies were not detected (Bulanik) is located on a hillside. There is neither stream nor marshland in its vicinity, nor is the geography of the area conducive to the accumulation of rainwater. These circumstances demonstrate the need to evaluate the villages in the region sepa- 
rately in respect of fasciolosis. It is of the utmost importance in the fight against the infection to map the prevalence of fasciolosis in these villages and to identify the habitats of the intermediate host.

Sole cattle farming is very common practice in some villages in Kars, whereas sole sheep farming is very rare. The reasons for this may be various: the nature of the terrain, demand factors, including the requirement for cow's milk, and, above all, the susceptibility of sheep to certain diseases, in particular parasitic diseases like fasciolosis, may lead farmers to favour cattle farming or mixed farming over sole sheep farming. In this study, in three of the four villages where both sheep and cattle were tested, the seroprevalance of the infection in sheep was $100 \%$, and in the fourth $97.9 \%$, whereas prevalence in cattle in the same villages ranged from $58 \%$ to $76 \%$. The difference in the rate of prevalence between cattle and sheep in the same villages may be attributable to differences in grazing management. Whereas cattle are returned to indoor feeding in mid-October, sheep continue to be grazed on the remaining areas of green pastureland until these are covered by deep snow in winter, which may be as late as December, potentially increasing the likelihood of sheep acquiring late autumn infection. Nevertheless, this hypothesis needs to be investigated in an independent study.

In conclusion, it is clear that infection with fasciolosis is widespread in cattle and sheep in the region of Kars; that the level of exposure to the infection of farm animals in the area is very high, contrary to the findings from abattoirs; and that the level of risk to which animals are subject varies between localities. It is also evident that the development of an effective control strategy to combat this infection and to minimise its potentially very damaging economic effects on the livestock industry requires, as a matter of urgency, the performance of comprehensive epidemiological studies, including the mapping of the prevalence of fasciolosis in the region and the determination of the seasonal distribution of the parasite and of its intermediate hosts.

\section{References}

AKCA, A. (1999): Cytokine, cellular and humoral immune responses in calves experimentally-infected with Fasciola hepatica. $\mathrm{PhD}$ Thesis, UK, Liverpool: University of Liverpool

AKYOL, C. V. (2003): History and epidemiology. In: TINAR, R., KORKMAZ, M. (Eds) Fasciolosis. İzmir, Turkey: Turkish Society for Parasitology, Publication no. 18: $85-$ 106 (In Turkish)

Duscher, R., Duscher, G., Hofer, J., Tichy, A., Prosl, H., JOACHIM, A. (2011): Fasciola hepatica - Monitoring the milky way? The use of tank milk for liver fluke monitoring in dairy herds as base for treatment strategies. Vet. Parasitol., 178, 273 - 278. DOI: 10.101/j.vetpar.2011.01.040

Gargili, A., Tuzer, E., Gulanber, A., ToparlaK, M., EfIL, I., Keles, V., Ulutas, M. (1999): Prevalence of liver fluke infections in slaughtered animals in Trakya (Thrace) Turkey. Turk. J. Vet. Anim. Sci., 23, 115 - 116

GiciK, Y., Arslan, M. O., KarA, M., AKCA, A. (2002): Prevalence of liver flukes in sheep slaughtered in Kars province. Kafkas Univ. Vet. Fak. Derg., 8, 101 - 102 (In Turkish).

HAPPICH, F. A., BORAY, J. C. (1969): Quantitative diagnosis of chronic fasciolosis. 1. Comparative studies on the quantitative faecal examinations for chronic Fasciola hepatica infection in sheep. Aust. Vet. J., 45, $326-328$

HILlYER, G. V. (1999): Immunodiagnosis of human and animal fasciolosis. In: DALTON, J. P. (Ed) Fasciolosis. Wallingford, Oxon, UK: CABI Publishing, pp. 435 - 448

KURTPINAR, H. (1957): Parasites of cattle, sheep and goats specific to the summer months in the provinces of Erzurum, Kars and Ağri, and the diseases they cause. Turk. Vet. Hek. Dern. Derg., 27, 3320 - 3325 (In Turkish)

LELOGLU, S. (1972): A comparative study of livers with and without liver Flukes (Fasciola hepatica) for clostridial infections by means of culture and by fluoroscent antibody technique. Turk. Vet. Hek. Dern. Derg., 42, 19 - 22

Molloy, J. B., Anderson, G. R., Fletcher, T. I., LANDMANN, J., KNIGHT, B. C. (2005): Evaluation of a commercially available enzyme linked immunosorbent assay for detecting antibodies to Fasciola hepatica and Fasciola gigantica in cattle, sheep and buffaloes in Australia. Vet. Parasitol., 130, 207 - 212. DOI: 10.1016/ j.vetpar.2005.02.010

Rapsch, C., Schweizer, G., Grimm, F., Kohler, L., Bauer, C., Deplazes, P., Braun, U., Torgerson, P. R. (2006): Estimating the true prevalence of Fasciola hepati$c a$ in cattle slaughtered in Switzerland in the absence of an absolute diagnostic test. Int. J. Parasitol., 36, 1153 - 1158. DOI: 10.1016/j.ijpara.2006.06.001

SAlimi-Bejestani, M. R., MCGarry, J. W., Felstead, S., OrTIZ, P., AKCA, A., WILliAMS, D. J. (2005): Development of an antibody-detection ELISA for Fasciola hepatica and its evaluation against a commercially available test. Res. Vet. Sci., 78, 177 - 181. DOI: 10.1016/j.rvsc.2005.08.005 SARIMEHMETOGLU, H.O. (2002): Application of western blotting for the immunodiagnosis of Fasciola hepatica in cattle using excretory/secretory antigens. Turk. J. Vet. Anim. Sci., 26, 1061 - 1065

TINAR, R. (2003): Life cycle. In: TINAR, R., KORKMAZ, M. (Eds) Fasciolosis. İzmir, Turkey: Turkish Society for Parasitology, Publication no. 18: 13 - 42 (In Turkish)

Torgerson, P., Claxton, J. (1999): Epidemiology and Control. In: DALTON, J. P. (Ed) Fasciolosis. Wallingford, Oxon, UK: CABI Publishing, pp. 113 - 149 